\title{
Leadership in Community-Based Organizations: What Fisheries Comanagement Teaches Us?
}

\author{
Abdullah Al Mamun (Corresponding author) \\ Department of Geography and Environmental Studies, Wilfrid Laurier University \\ 75 University Ave West, Waterloo, Canada
}

Received: February 27, 2015 Accepted: March 19, 2015 Published: March 24, 2015

doi:10.5296/ijssr.v3i1.7311 URL: http://dx.doi.org/10.5296/ijssr.v3i1.7311

\begin{abstract}
This study perceives leadership roles from various concepts and theoretical standpoints that are further evaluated in connection with fisheries comanagement programs of Bangladesh. A case study approach combining six project areas of Southern Bangladesh was used so that a broader understanding can be developed about leadership roles in comanagement. In total 15 months of data collection were conducted. It was found that local leaders of comanagement programs play key roles in maintaining local forums such as organizing community groups and representing communities at other scales (e.g., district level meetings). However, some contentious issues such as local corruptions and higher number of non-fisher participants in leadership positions have marred the success of comanagement. It was also found that factors such as education, gender and social positioning have a strong influence (often negative) on local leadership processes limiting the scope of achieving social goals of comanagement programs. Therefore, comanagement programs have become both part of praise and criticism in the issue of leadership roles.
\end{abstract}

Keywords: Fishers, leadership, participation, comanagement, stakeholders

\section{Introduction}

It is widely believed that fisheries and other aquatic resources have been degrading worldwide for over-harvests, alteration of fish habitats for flood protection and related hydraulic structures (e.g., cross-dams) that block migration and spawning of fishes. For similar types of anthropogenic stresses, small-scale fisheries in inland open waters have degraded greatly in Bangladesh. As per published records, open water fisheries contributed 55.65\% of the total catch in FY 1985-86 which reduced to 41\% in FY 2005-06 (DoF 2010 and 2011; Dey et al., 2008). To avert resource degradation and formulation of management plans based on better accommodation of local users need with the resource (e.g., livelihood of fisheries), the current reality is the introduction of participatory management approaches (e.g., 
comanagement) of fisheries (Berkes, 2007; Borini-Feyerabend et al., 2007; Plummer \& Fennel, 2007; Balint \& Machinya, 2006; Pinkerton, 2003, 1989; Jentoft, 1989). Collaboration and empowerment of local users have been the key elements of such approaches (Prager 2010; Pero \& Smith 2008; Plummer \& FitzGibbon 2006). Going beyond the conventional forms of decision-making such as informing or consulting people by state bodies about a program which are lower level of participation (Arnstein, 1969), a joint collaboration in recent models of partnership such as comanagement can play a supportive roles towards fisheries governance in a variety of ways. These include: higher level of communication, resource sharing, enhance linkages to reduce disconnections between state and others as well as engage measures which are more adapted to local social-ecological contexts (Foale et al., 2012; Bene et al., 2011; Armitage et al., 2008; Berkes \& Jolly 2001). These types of management approaches also help resource dependent communities in taking common actions such as joint surveillance (Hauzer et al., 2013; Prager, 2010; WorldFish, 2007; Thompson, 2003; Treseder, 2000). The more recent participatory approach also involves livelihood framework (Scoones, 1998) along with development of natural capital (ecosystems) and social capitals (institutions, networks, etc.) which certainly have broadened the scopes comanagement to face recent and future challenges in small-scale fisheries governance (Ratner et al., 2012). In this regard, a common assumption is that when the dominant governance approaches supported by states such as fish moratoriums/banning and market-based approaches that apply tools such as Total Allowable Catches (TACs) have failed to deal with complexities within fisheries systems (Imperial \& Yandale, 2005), comanagement has been flourishing as a civic approach to resource governance (Plummer \& FitzGibbon, 2006). Given the above understanding, interests about comanagement have grown to resource managers, users and scholars about the effectiveness of the approach. With respect to evaluation of impacts of comanagement on natural resource governance, a great deal of research has been done highlight plentitude of advantages of comanagement processes. These include: conflict resolution, shared management and self-rules, resource sharing among actors of natural resources etc. (Boroni-Feyerabend et al., 2007; Fisher et al., 2007; Berkes \& Jolly 2001). Although an inexhaustible interest continues to escalate surrounding comanagement highlighting it as an effective measure for resource governance (e.g., Armitage et al., 2008; Berkes, 2007; Ross et al., 2005; Jentoft, 1989), one area has not been covered yet is the influence of comanagement on leadership roles in fisheries sectors (Gutiérrez et al., 2011 and this study). Recent studies have indicated that comanagement typically fails or face various challenges without prominent community leaders delivering guidance and services for local groups engaged in community-based resource governance (Doremus, 2011; Gutierrez et al., 2011; Pero \& Smith, 2008; Berry \& Gordon, 1993). While emphasis is given by researchers to leadership roles, evidence from empirical studies focusing the significance of such local leadership in comanagement is lacking. Therefore, the leadership development process needs further investigation concerning progress made by comanagement. This study is to investigate the leadership development process in grassroots level institutions called Community-Based Organizations (CBOs) that deal with small-scale fisheries comanagement of Bangladesh. It especially, looks at how the local leadership process has evolved (e.g., Leadership processes) and who gained and who lost from this 
process and what is the key issues comanagement has been facing in leadership development processes for empowerment of local organizations responsible for managing small-scale fisheries in wetlands of Southern Bangladesh (Figure 1). In this regard, influence of education, incomes, issues of gender and asset dimensions of leadership roles are investigated to understand how comanagement process is influenced by these attributes in local forums called Community-Based Organizations (CBOs). These issues have theoretical and practical significances as local empowerment has been part of the project goals of fisheries comanagement supported by donors or initiated by state bodies, where participation of women and the poor is lacking (OPR-4 2005; Uphoff, 1999). It is hoped that this paper can provide useful insights with regard to leadership roles under comanagement models concerning fisheries governance where no much research has been done. This study may interest managers and researchers, locally and globally who is involved in governance of fisheries and any other natural resources through the application of participatory models including comanagement.

\section{The Leadership Roles: Theoretical Perspectives and Significance}

Leadership roles are investigated in social science literature in connection with organizational and social settings. In general, leaders and followers are treated as collaborative agents in the transformation of social reality (Pero \& Smith, 2008; Reitcher et al., 2005). In this regard, various scholarships have defined leadership roles differently. Many past and present researchers have contended leadership as an important feature of everyday life and organizational affairs (Reitcher et al., 2005; van Knippenberg et al., 2004; Parry \& Bryman, 1996). Leadership roles are perceived as an influence on one of the others to setting purposes and goals for groups that are involved in accomplishing certain tasks (Tyler \& De Cremer, 2005; van Knippenberg et al., 2004). Additional to that, leadership is viewed through other means such as supporting, coaching, and directing that are related to delegating group environment that are often related to the performance of organizations (Murphy, 2005). It is also contended by theorists that efficient leadership may lead to better organizational outcomes leading to improved group performance (Bolden et al., 2003). Reviewing vast amount leadership literature on their roles, Pero and Smith (2008) identified various features of leaderships which include: being dependent on followers; being critical in mobilizing a group to take action; and being instrumental in promoting changes in a society.

As per Stogdil (1974), leadership is an act of influence of the activities of an organized group in efforts toward achieving common goals such as what we see in a small firm and business environments. With respect to leadership, Adair (2003) contends that leadership roles are often action centered and a motivation for others in encouraging group members to achieve certain goals. This type of leadership is called "Inspirational Leadership". A detailed review of the leadership literature done by Bolden and others (2003) reveals an evolving series of scholarships from very old concepts such as "Great Man Theory" and "Trait Theory" to more recent "Transformational Theory of Leadership" (Leithwood \& Poplin, 1992). It is noticeable from the varieties of concepts and theories discussed above that early theories have tended to focus upon the behavioral aspects of successful leaders while more recent theories (e.g., Pero \& Smith, 2008; Murphy, 2005) begin to consider the role of group members and the 
contextual nature of leadership roles to understand the success and failure of organizations. Traditional theories also take a rather individualistic approach to leadership roles. However, more recent theories cover broader aspects of leadership such "dispersed” forms of leadership in a group rather than focusing on individuals (Gordon, 2008). Therefore, the emphasis on leadership research thus has shifted from developing 'individual leaders' to developing "Leaderful” organizations. This concept views leadership as a collective responsibility and disregard the influence of a few individuals for others (Bolden et al., 2003). Developing collective leadership through informal institutional arrangements and distribution of management responsibilities to resource users have been a major tenet for comanagement approach as well. It is because comanagement prompts multi-stakeholder approach by combing all users affected. However, comanagement programs and empowerment processes often fail to achieve its multiplicity of goals for local corruptions and uneven power relationships (elite captures) between leaders and followers (e.g., Gutierrez et al., 2011; Plummer \& Fennel, 2007; Pomeroy \& Rebecca, 2006; Platteau \& Gaspart, 2003; Uphoff, 1999). This paper elaborates perception of leadership in connection with comanagement where the roles of leaders, selection process for good leaders, influence of education and social positioning have been key considerations.

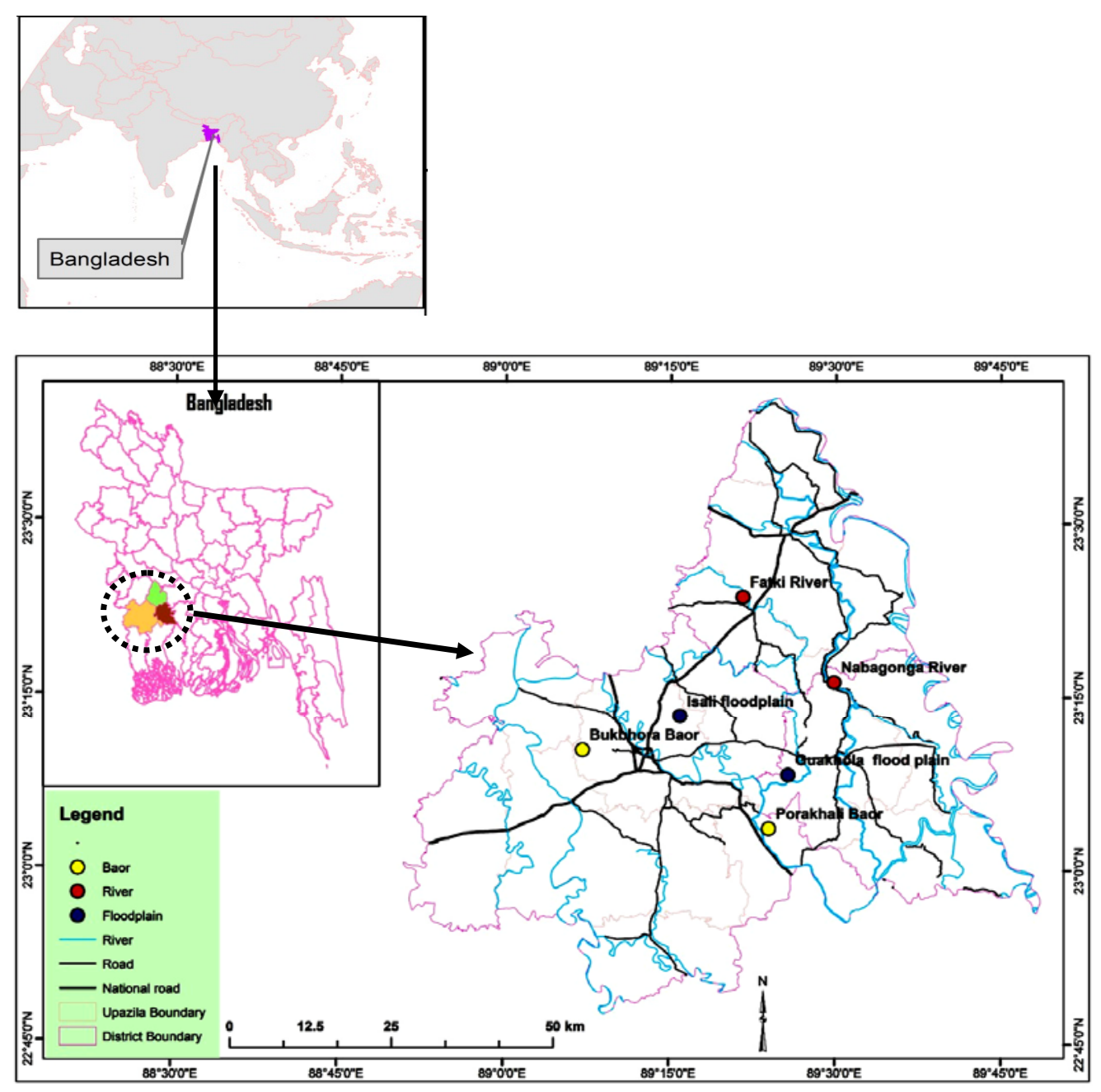

Figure 1. Map of Bangladesh showing location of study sites 


\section{Profile of the Study Area}

The study was conducted in the greater Jessore District of Bangladesh (See Figure 1) which includes six water bodies from three categories of small-scale fisheries systems including Floodplains (e.g., Isali and Goakhola), Oxbow Lakes (e.g., Bukbhora and Porakhali) and Rivers (e.g., Nabogonga and Fatki).

All of these aquatic systems included in this study were important sources of capture fisheries for surrounding villages but degraded for agricultural uses, water controlling structures, fishing pressures and uncontrolled harvests of aquatic resources (SEHD 2002). Under the comanagement programs the management approaches of the water bodies were informal such as through locally formed management committees called Community-Based Organizations (CBOs). In such arrangement community could select or elect their leaders based on past contributions of the individuals to the society, mentorship or status in a society. Leadership roles were key surrounding CBOs. The CBO activities which were exercised under the guidance of local leaders include: setting monitoring groups for checking illegal fishing, managing fishing schedules (fixing spots and timing of fishing etc.) and implementing fish rules in concurrence with the existing policies (e.g. National Fish Policy 1998) and Acts (e.g., Fish Conservation and Protection Act 1950 of Bangladesh). CBO leaders also assigned for handling small funds available to communities from project grants or yearly membership fees. The CBOs had various types of positions held by community leaders (Presidents, Secretaries and Cashiers) but not always the cases that holders of the positions are from traditional fishing communities. Inclusion of richer people in leading positions, however, was not the strategies of comanagement programs as most programs were directed towards empowerment of poor fishers (the ethnic fishers called Jalyes) or farmers who are depended on fishing for fulltime and part-time incomes.

As leading positions are taken over by non-fishers and rich members of the society, it has been a major concern for traditional fisheries and question arose from many users such as do comanagement programs support the most affected groups (e.g., the Jaleys) for the losses of open water catch? Therefore, investigating leadership roles process in CBOs can provide an important insight about comanagement programs supporting resource governance.

\section{Methodological Considerations}

The theoretical framework of this research was both social science (e.g., Adair, 2003; Bolden et al., 2003; Leithwood \& Poplin, 1992) and common property literature (Berkes et al., 2001; Ostrom, 1990; Berkes, 1989). This study included a Case Study-Based Approach (See Yin, 2002) along with pragmatic dualism (mixed method) which includes both qualitative and quantitative approaches to data collection and analysis (Creswell, 2008). For understanding leadership roles among study sites a comparative research design was used. Three Participatory Rural Appraisal (PRA)-based approaches (e.g., Focus Groups, Semi-structured interviews, and participant observations) were used in combination to reduce data gaps (Townsley, 1996). Primary data were collected for two seasons in 2011 and 2012. Local stakeholders such as CBO members (fishers/framers/fish traders- $\mathrm{N}=78)$, CBO leaders $(\mathrm{N}=18)$ 
and officials (15) are included as respondents in the primary data collection process. In total seven group meetings were conducted. Interviews were recorded, transcribed and translated. Data were coded according to the themes evolved and questionnaires used. This research also contains reviews of secondary data. The vast majority of secondary data was collected from published and unpublished data available to WorldFish Center, Dhaka, and the local agent of UKaid (UKaid, 2010). Many of the secondary data are collected from community sources such as record books, brochures and posters available to local leaders managing CBOs.

\section{Results}

This study includes various insights related to leadership roles towards comanagement processes. Assessment of leadership roles is done based on the relative contributions of leaders towards functioning CBOs, perceptions of general members about good leaders, level of engagement of key stakeholders such as fisheries and less voiced member such as women. It revealed from this study that leaders have performed various tasks that have supported comanagement such as voluntary services by the leaders (often leaders received no direct advantages from being a leader except few benefits such as day allowances for attending meetings at cities). In some cases, leaders have donated plots for construction of CBO centers such as Fatki River site. Given this, leadership roles can be perceived as inspirational for general members (as confirmed by Bolden et al., 2003) that certainly have motivated general members to work for CBOs. In return leaders have received some training such as writing meeting resolutions and organizing meetings. Leaders were also given priority to attend skill development trainings focusing livelihoods, such as fish cultivation, biogas with an intention that they would discuss the learning with general members. For CBOs local leaders were the key contacts on behalf of community for external affairs communicating Department of Fisheries, NGOs and Donors working in Bangladesh. For achieving community goals they (leaders) have performed several duties related to organized activities that have enhanced group performance. For example, CBO leaders were responsible for organizing community meetings to discuss fisheries related tasks such as guiding joint surveillance programs attended by DoF and community in the case of violation of fisheries rules during the moratorium declared by government (July- September) for safe breeding of fishes. Given the above understanding, CBO leadership roles in comanagement can be perceived as “Action Centered” as contended by Adair (2003). As a result, finding good leaders were key concerns for community and project proponents such as WorldFish Center, DoF, and Donors (WorldFish, 2007, 2003). The following sections assess leader selection process which is further defined in connection factors such as education; gender and social positioning that have influenced leadership processes in the comanagement of fisheries.

\subsection{Leadership Process: Determinants of a Good Leader}

In comanagement programs leaders were chosen by general members through the selection process and formal elections were mostly avoided for related costs (e.g., printing posters) or group influence that may lead to inclusion of unwelcomed members in leadership roles. Members have selected leaders based on their past mentorship to be engaged in community affairs in a meaningful way so that success in the management of the fisheries systems can be 
achieved under the directions of leaders. The range of qualifications, skills or virtues of a person was used in order to select a good leader by CBO members is included in Table 1. Among all of the qualities, CBO members' higher preference was that their leaders would have to be educated; economically solvent which most general fishers do not have and eventually they are excluded from the leading positions (Table 3).

Table 1. List of types of skills/virtues needed to be CBO leaders (based on 96 respondents who are local fishers)

\begin{tabular}{|c|c|c|c|c|c|c|c|c|}
\hline $\begin{array}{l}\text { Type of Qualities/ } \\
\text { Skills/Virtues }\end{array}$ & Goakhola & Isali & Bukbhora & Porakhali & Fatki & Nabogonga & $\begin{array}{c}\text { Total } \\
\text { positive } \\
\text { responses }\end{array}$ & (\%) \\
\hline Education & 13 & 11 & 12 & 16 & 15 & 5 & 72 & $75 \%$ \\
\hline $\begin{array}{l}\text { Economically } \\
\text { solvent }\end{array}$ & 11 & 11 & 14 & 11 & 11 & 5 & 63 & $66 \%$ \\
\hline Honesty (finance) & 7 & 3 & 7 & 7 & 12 & 4 & 40 & $42 \%$ \\
\hline Liaison & 1 & 6 & 6 & 7 & 7 & 7 & 34 & $35 \%$ \\
\hline Friendliness & 5 & 7 & 5 & 7 & 7 & 1 & 32 & $33 \%$ \\
\hline Intelligent & 4 & 4 & 5 & 7 & 5 & 5 & 30 & $31 \%$ \\
\hline $\begin{array}{l}\text { Past leadership } \\
\text { roles }\end{array}$ & 5 & 7 & 5 & 6 & 4 & 3 & 30 & $31 \%$ \\
\hline $\begin{array}{l}\text { Fishing } \\
\text { livelihoods }\end{array}$ & 5 & 7 & 7 & 1 & 1 & 5 & 26 & $27 \%$ \\
\hline $\begin{array}{l}\text { Organizing } \\
\text { capacity }\end{array}$ & 1 & 4 & 6 & 5 & 4 & 6 & 26 & $27 \%$ \\
\hline Negotiation skills & 1 & 5 & 5 & 1 & 1 & 4 & 17 & $18 \%$ \\
\hline Good listener & 1 & 3 & 1 & 1 & 3 & 0 & 9 & $9 \%$ \\
\hline $\begin{array}{l}\text { Problem solving } \\
\text { Skills }\end{array}$ & 2 & 3 & 1 & & & 0 & 6 & $6 \%$ \\
\hline Clear speech & 4 & 0 & 0 & 0 & 0 & 0 & 4 & $4 \%$ \\
\hline $\begin{array}{l}\text { Active } \\
\text { membership }\end{array}$ & 0 & 0 & 0 & 0 & 0 & 3 & 3 & $3 \%$ \\
\hline Accountable & 1 & 0 & 0 & 0 & 0 & 0 & 1 & $1 \%$ \\
\hline Total Responses & 61 & 71 & 74 & 69 & 70 & 48 & - & - \\
\hline
\end{tabular}

(Source: Summary of responses on interviews of 18 local participations from each site)

However, during my field visits, I found that most meeting resolutions were written with the help of NGO members such as Porakhali site. So the community perception of education as a determinant of a leader was not consistent in many cases. This information indicates that incapability in CBO leaders also exists in leadership processes. As a solution to the issue, many younger people of the communities feel that CBO activities can be improved by including some younger members who are educated and can manage clerical jobs. However, the CBO members disapprove the entry of youths who are sometimes politically involved. It is to be noted that state politics are generally violent and confrontational in Bangladesh 
(Pirnini 2011; Amundsen1997), which discourages the entry of younger members in CBO processes, too. Older members of CBOs felt that any influence of politics in CBO processes can disrupt the continuation of local forums and overall management of fisheries. However, the disapproval for younger generation runs the risk of gaps in future leadership processes.

\subsection{Leadership Process: Influence of Education, Asset and Social Identity}

An investigation related to participation in community-based organizations was done based on three main attributes such as education, professional affiliations and yearly incomes of CBO leaders that define social status in rural communities. I found that in the majority of comanagement projects poor groups have been more involved as general members while the rich people who have jobs, good education and who are wealthy hold the leadership roles although all comanagement projects advocated for empowerment of local disadvantaged groups such as traditional fishers. In this regard, Table 2 indicates that CBO leaders are individuals who are mostly educated with 6-12 years of schooling while fishers are not educated or do not have good jobs. As poor fishers are simply not educated they were excluded from leading positions such as president, secretary and cashiers. As per Table-3 we can see that all of the key leading seat holders were either professionals or retired members and very few are from fisher groups. As we can see in Table-3 that only three local leaders (they are in bold) are from full-time fishing profession (16\%) of which two of them are from a non-significant project site such as Nabogonga (ran for only two years).

Table 2. Year of schooling of group leaders in CBOs

\begin{tabular}{ccccccc}
\hline Attributes & Goakhola & Isali & Bukbhora & Porakhali & Fatki & Nabogonga \\
\hline President & 10 & 12 & 7 & 8 & 7 & 6 \\
Secretary & 8 & 7 & 12 & 12 & 9 & 10 \\
Cashier & 6 & 12 & 11 & 8 & 8 & 12 \\
\hline
\end{tabular}

(Source: Focus Groups at study sites, 2011)

Table 3. Professional affiliations (based on main professions) for group leaders

\begin{tabular}{|c|c|c|c|c|c|c|c|}
\hline Attributes & Goakhola & & Isali & Bukbhora & Porakhali & Fatki & Nabogonga \\
\hline President & $\begin{array}{l}\text { Retired } \\
\text { Servant }\end{array}$ & Public & $\begin{array}{l}\text { Retired } \\
\text { Army } \\
\text { Officials }\end{array}$ & Fishing & Farming & Farming & $\begin{array}{l}\text { Farming and } \\
\text { Jobs }\end{array}$ \\
\hline Secretary & , & & $\begin{array}{l}\text { School } \\
\text { Teacher }\end{array}$ & Farming & , & , & Fishing \\
\hline Cashier & $\begin{array}{l}\text { Fishing/ } \\
\text { Farming }\end{array}$ & & Farming & $\begin{array}{l}\text { Farming/ } \\
\text { Business }\end{array}$ & , & , & Fishing \\
\hline
\end{tabular}

(Source: Focus Groups at study sites, 2011) 


\section{Macrothink}

\subsection{Leadership Process: Group and Gender Sensitivity}

Like poor fishers, women's participation in the project was generally lacking in all CBOs. This study found that women's participation in CBOs is generally lower in the CBO process except the inclusion of a few women as general members in most recent projects such as Community-Based Fisheries Management (CBFM) Phase 1 (1999-2000) and Phase 2 (2001-2006) while older projects (Bukbhora and Porakhali sites) had no women's participation yet though there running for last 15 years (See Figure 2).

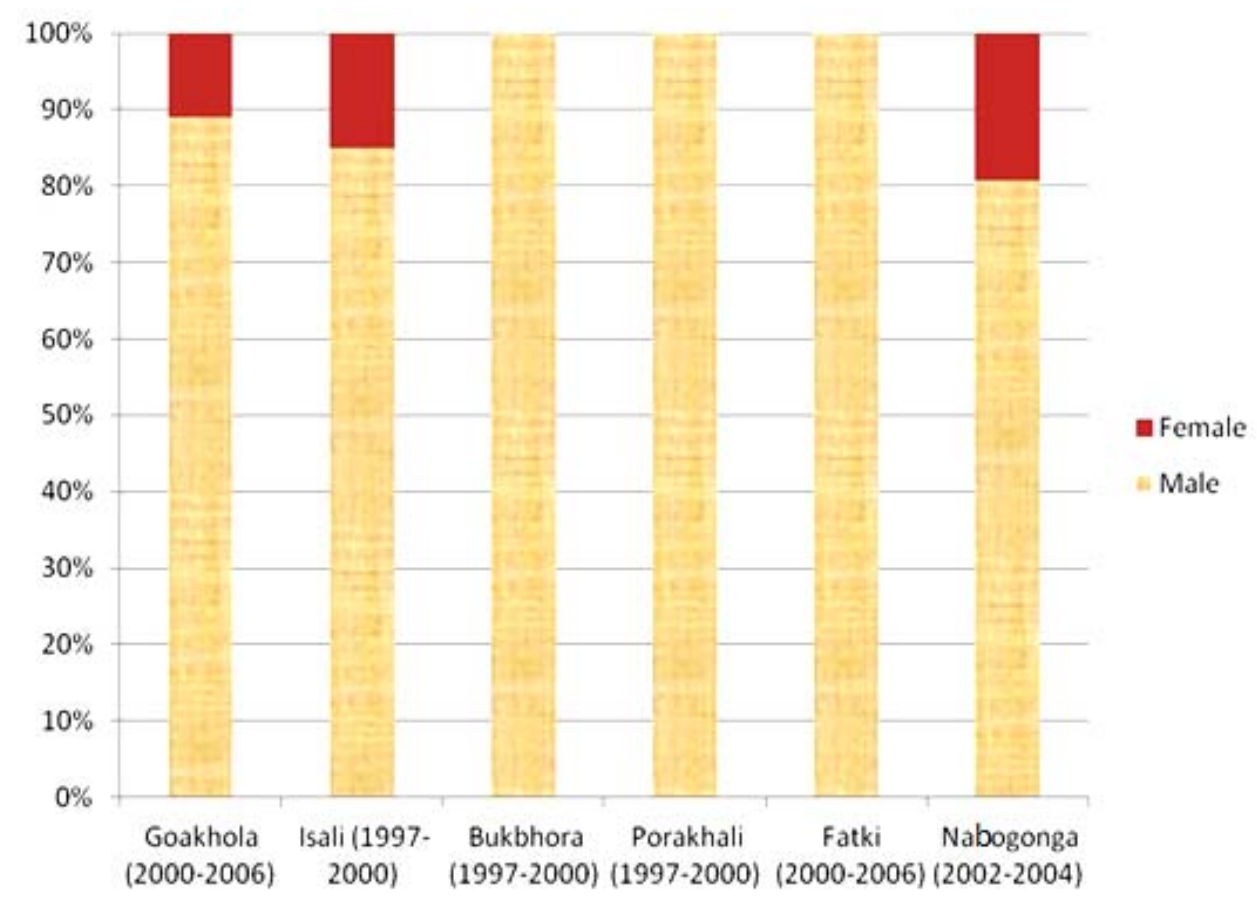

Figure 2. Proportion (\%) of male and female participants in CBOs

On a question related to participation of female members to positions such as CBO leaderships, the responses from general members found divided. Mostly they have counter questions such as how can women be a part of the leadership as they know nothing about fishing being they are homemakers (Leaders from Porakhali, February 2011)? In this regard I quoted a statement from a Leader below.

... Fishing is a hard work that male fishers can do only. We cannot include women in Baor fisheries (The Ox-bow Lake) because they are women. They do not know how to operate a boat or net. Our Baor is like 10-15 feet deep in some places. It's actually not possible for them to be fishers-Secretary of Porakhali Baor, Abhoynagar, Jessore District. However, in other cases such as Bukbhora site which is also a water body with no participation of women I found that some leaders are considerate about women's participation in this site too. I quoted a response about women's participation from a CBO leader as: 
... Working with fishing at the bar would not be a feasible option for women for cultural and safety reasons. But we are planning to include them in our new system of management by stocking of fish that is yet to start. However, this program is still at primary stage- Secretary, Bukbhora Baor, Jessore.

Though men are skeptic about women's participation, a good number of women participants and NGO personnel (e.g., Baste Shekha) believe that it is also possible to engage women through creating some positions that only need certain skills such as writing, accounting, preparing minutes or monitoring nearby fish ponds. Nonetheless, this type of step has not been considered yet. Given the above understanding with respect to the participation of fisher or poor households and women, it can be inferred that the comanagement in many cases is basically helping the empowerment of already empowered people in rural societies but not the fishing depended people who are poor or the women at large.

\subsection{Leadership Process: As Supportive Roles}

Although comanagement has failed to deal with some contentious issues such as participation of poor fishers and women, it could enhance fisheries management in other fronts. Comanagement, in general, advocates a multi-stakeholder processes which emphasizes inclusion of all stakeholders in governing a resource such as fisheries. Given this, comanagement of Bangladesh tried to adopt a democratic process with a vision of allowing expressions of views and concerns of local users in the decision making process. In this regard, comanagement process has made some advancement if we look at the leadership processes such as leadership roles in CBOs. For example, leadership roles were not confined in one person. For example, most decisions were made at general meetings. It was a practice for almost all CBOs that any resolutions should be supported by 60 percent of active members such as allocating loans from $\mathrm{CBO}$ funds in Goakhola site. This indicates that a dispersed form of leadership roles as described by Gordon (2008) (See Section-2) exists in $\mathrm{CBO}$ process. Also, it was understood from the interview participants and review of community records that more than one person could provide directions to fisher groups. For example, each CBO had 15 to 20 executive positions who were also group leaders at village levels. Group leaders at village levels also had certain powers to guide general members at village levels. For example, directing group fishing with larger seine nets and distribution of benefits from catch or sell prices. An interesting fact about CBO leadership processes was that personal satisfaction perhaps had been the main motivation towards attainments in leadership roles. As per views of CBO leaders in Goakhola site, leadership roles in CBO have given them an opportunity for older members of a society such as retired personnel to use their extra times in serving communities when they don't have much work to do. With regards to own satisfaction and happiness with leadership roles, most leaders agreed that it is their pleasure to serve the community as they are mostly respected in society. A leader from Porakhali site could win the membership election of 2008 what many believe that his credibility was upheld as he acted as a CBO leader in several terms. A CBO president from Goakhola site feels he can work for the community and remunerations, in fact, are not his main focus. With respect of response of leadership roles to general members, I found that, a free-rein or laissez-faire leadership exists at most of the CBOs as CBO leaders allow some 
levels of freedom to group members in deciding their own policies and maintaining protocols since leaders cannot or do not hold the supreme authority to lead over their members and members are allowed to leave or come back to CBO. In this regard, no overrated and romanticized perceptions of leadership roles were held by the general members except for some personal opinions of CBO leaders. For example, many leaders pointed out that they performed their roles for the benefits of local people, not for personal interests.

\subsection{Leadership Processes: Local Corruptions}

The previous section indicates that the leadership roles are not deplorable for the contribution individual leaders have made (plots for community, centers, volunteering services etc.). Leaders were also satisfied with their involvements. However, personal satisfactions of CBO leaders could not satisfy community members in many instances. This study identifies that general members have expressed various hopes, frustrations and distrust related to leadership roles in several project sites. In some cases, the project leaders were found unaccountable to general members and involved in some level of corruptions that marred some good achievements and long lived projects such as Isali (1997-2009). The project leaders of sites found to have misused the funds of general member that were coming from deposits made from fishing towards common funds of CBOs. General members complained to me that leaders kept their money on holds and used them for own purposes for undefined times (even for months) before deposited to banks under community funds. Moreover, they complained that the past leaderships were not free of greed such as relief materials for given for communities were not distributed among members but taken by leaders and no action was taken against them as they have political backings and treated as local elites. As such local leaders have used their statuary powers to benefit themselves and group senses have not been valued.

\section{Discussions}

This study indicates that local leaders have played various roles in CBO process. For example, leaders have played inspiring roles in supporting comanagement of fisheries. We have seen that local leaders have sacrificed their resources to sustain comanagement institutions. Community members were also innovative in choosing their leaders. They sometimes have elected leaders, but they also have avoided formal election processes which made leadership process flexible and adapted to local situations. Moreover, CBO leaders have divisions of labor that we see in most formal organizations. In the case of comanagement programs, all of the sites had three key leading seats in CBOs which include president, secretary and cashier. Nevertheless, local leadership processes have constrained by a number of factors. For example, poor fishers were mostly excluded from leadership roles they are being less educated. However, for a fisheries comanagement program it would not be the case that the traditional fisheries would be excluded from a leadership position for ever. Anyone simply may ask a question like if it is a fisheries comanagement then where is the fishers. Some other related factors also have marred the success of CBO in achieving project goals such as empowering women have not been possible through comanagement programs. We have seen that responses of male about female participation were not favorable towards women as 
males feel that women cannot do hard jobs like fishing. Some capabilities of women such as skills related to accounting and engage them in tasks including feeding of fishes were not approved by men to uphold their participation. Similarly, the younger generation was discouraged by the older members claiming that their involvement in political parties that are often violent which may risk the CBO processes. Given this understanding, it can be stated that comanagement somewhat is empowering the empowered section of the community and the leadership process has replicated the social order e.g., males are the ones to decide how the comanagement would look like. Moreover, the local leadership process could not come out of corruptions, and it was not free of selfish behaviors. These types of lacks of legitimacy and honesty in social systems have affected CBOs successes negatively. This finding parallels the finding of early researchers like Platteau and Gaspart (2003) and Uphoff (1999) who confirmed corruptions of local leaders in projects funded by donors that have constrained local empowerment in third world countries. This study reconfirms the issue but corruptions have occurred in a different manner. Leaders have used community funds but not the project money. In CBOs, community leaders have not taken the money of general members for a long term basis but used them for the time being. This study, therefore, discovers a new dimension of local corruption that has theoretical and practical significance.

There are several other dimensions to verify leadership roles in CBOs. It may be argued that comanagement could not influence local power structures in fisheries systems though it was innovative in many ways such as engaging local fisheries in joint fishing and sharing of benefits. For example, leadership roles were action-centered as viewed by Gordon (2008) but not much to bring social changes that were expected in comanagement and which are also goals of donor funds. It is also understandable that leadership processes have not realistically favored the poor groups but benefited certain individuals (the leaders who got trainings and hold leading positions that enhanced their social standing) at the cost of the others especially the poor fishers (The Jaleys). So comanagement can serve as tool to meet the agenda of donor funds who want to see wider participation while key resource users may further marginalized to a certain extent (The Jaleys). Therefore, the leadership roles in CBO process have been part of both praise and criticisms.

\section{Conclusion}

This study highlights that comanagement programs have not been favorable in achieving empowerment of local fisher and women that was the goal of fisheries development programs funded by donors. It is also understandable that many of the concerns related to issues of participation are of social origin such as men are skeptical about women participation. Similarly socio-political situations also disfavored participation of younger generation. So comanagement has set a short-term vision to fisheries governance. To overcome some of the contentious issues related to leadership processes several strategies can be proposed. One way would be to adopt mixed forms of leadership roles which may include exiting leaders with newer ones to be commissioned gradually from poor groups, women and younger people under comanagement programs. Similarly, as poor fishers could not join CBOs because they are not educated and their social standings were also not favorable to be so, some leading positions can be reserved for traditional fishers as a priority basis. So that they 
gradually can learn to take responsibility CBO processes to maintain fair participation in comanagement processes. Moreover, to avoid local corruptions, some motivational programs can be incorporated in comanagement so that leadership roles can be improved (see Platteau \& Gaspart, 2003). Future research can be directed to investigate how leadership roles can be more favorable towards comanagement programs in resource scared and feudalistic societies that exist in many counties including Bangladesh where leadership roles are influenced by social status, gender and education, not by the nature of the resource to be managed or communities are involved.

\section{Acknowledgements}

My special thanks to the community members and other stakeholders of the Fisheries Comanagement Program of the WorldFish Center, Bangladesh, who gave me the opportunity to discuss various management issues related to leadership development in local settings. I also would like to express my gratitude to Dr. Derek Armitage, University of Waterloo and Dr. Scott Slocombe, Wilfrid Laurier University, Waterloo, Ontario for their assistance guiding the research and preparing this manuscript. I also equally acknowledge the contribution of Dr. Paul M. Thompson, Former Project Director, WorldFish Center, and Senior Scientist Dr. Parvin Sultana, WorldFish Center, Dhaka, Bangladesh and many of my former collogues there including Dr. M. G. Mustafa, Md. Firoz Khan, Mr. Habibur Rahman, Md. Akter Hussain, Mr. Hasibur Rahman who extended their supports in conducting the research; provided access to the WorldFish Database system and archival records; and offered other suggestions that benefited the study. I extend my sincere thanks to my friend Dr. Alan Potkin of the University of Illinois and Jeremy Pittman, Waterloo University for their supports in developing the manuscript. This research was funded by the International Development Research Center (IDRC), Canada (www.idrc.ca/) and by Wilfrid Laurier University and the Dr. John McMurry Research Chair.

\section{References}

Adair, J. (2003). The Inspirational Leader: How to Motivate, Encourage \& Achieve Success. London: Kogan Page Ltd.

Amundsen, I. (1997). Political corruption: An introduction to the issues. Retrieved from http://www.consocial.cgu.gov.br/uploads/biblioteca_arquivos/122/arquivo_05f01e79ad.pdf

Armitage, D., \& Others. (2008). Adaptive co-management of social-ecological complexity. Frontiers in ecology and environment.

Arnstein, S. R. (1969). A Ladder of Citizen Participation. JAIP, 35(4), 216-224. http://dx.doi.org/10.1080/01944366908977225

Balint, P. J., \& Mashinya, J. (2006). The decline of a model community-based conservation project: Governance, capacity, and devolution in Mahenye, Zimbabwe. Geoforum, 37, 805-815. http://dx.doi.org/10.1016/j.geoforum.2005.01.011

Bene C., Evans, L., Mills, D., Ovie, S., Raji, A., Ahmadu, T., Andrew, N. L. (2011). Testing resilience thinking in a poverty context: experience from the Niger River basin. Global Environmental Change, 21, 1173-1184. http://dx.doi.org/10.1016/j.gloenvcha.2011.07.002 
Berkes, F. (1989). Common Property Resources - Ecology and Community Based Sustainable Development. London: Belhaven Press

Berkes, F. (2007). Community-based conservation in globalized World. http://dx.doi.org/10.1073/pnas.0702098104

Berkes, F., \& Jolly, D. (2001). Adapting to climate change: social-ecological resilience in a Canadian western arctic community. Conservation Ecology, 5(2), 18. Retrieved from http://www.consecol.org/vol5/iss2/art18

Berkes, F., Mahon, R., McConney, P, Pollnac, R., \& Pomeroy, R. (2001). Managing small-scale fisheries: alternative directions and methods. International Development Research Centre, Canada.

Berry, J. K., \& Gordon, J. K. (1993). Environmental Leadership: Developing effective skills and styles. Washington: Island Press.

Bolden, R., Gosling, J., Marturano, A., \& Dennison, P. A. (2003). Review of leadership theory and competency frameworks centre for leadership studies. University of Exeter.

Borini-Feyerabend, G, Pimbert, M., Favar, M. T., Kothari, A., \& Renard, Y. (2007). Sharing power: Learning-by-Doing in comanagement of natural resources throughout the world. Earthscan, London.

Creswell, J. W. (2008). Research Design: Qualitative, Quantitative, and Mixed Methods Approaches. 296 pages SAGE Publications Inc.; Third edition (23 Jul 2008)

Dey, M. M., Bose, M. L., \& M. F. (2008). Recommendation domains for pond aquaculture. Country case study: Development and status of freshwater aquaculture in Bangladesh. WorldFish Center Studies and Reviews. No. 1872. The WorldFish Center, Penang, Malaysia. 73 pages

DoF (Department of Fisheries, Bangladesh). (2011). Souvenir, Fish Fortnight Bangladesh 2011. 84 pages

DoF (Department Of Fisheries, Bangladesh). (2010). Annual Report.

Doremus, H. (2011). What makes fisheries co-management successful? Legal planet, Environmental law and Policy blog. UCLA. Retrieved from http://legalplanet.wordpress.com/2011/02/04/what-makes-fisheries-co-management-successf $\mathrm{ul} /$

Fisher, R., Prabhu, R., \& McDougall, C. (2007). Adaptive Collaborative Management of Community Forests in Asia: Experiences from Nepal, Indonesia and the Philippines. Center for International Forestry Research PP.142. Governance and Ecology, 1(3/4), 199-222.

Fish Protection and Conservation Act. (1950). C/O Department of Fisheries, Dhaka Bangladesh

Foale, S., Adhuri, D., Aliño, P., Allison, E. H., Andrew, N. L., Cohen, P., Weeratunge, N. 
(2012). Putting people at the centre of the Coral Triangle Initiative. Marine Policy, 34, 174-183.

Gordon, R. D. (2008). Dispersed leadership, power and change: An empirical study using a critical management framework. Retrieved from http://epublications.bond.edu.au/cgi/viewcontent.cgi?article=1116\&context=business_pubs

Gutiérrez, N. L., Hilborn, R., \& Omar, D. (2011). Leadership, social capital and incentives promote successful fisheries. Nature, 470, 386-389. http://dx.doi.org/10.1038/nature09689

Hauzer, M., P. Dearden, G. Murray. (2013). The effectiveness of community-based governance of small-scale fisheries, Ngazidja Island, Comoros. Marine Policy, 38, 346-354. http://dx.doi.org/10.1016/j.marpol.2012.06.012

Imperial, M. T., \& Yandale, T. (2005). Taking Institutions Seriously: Using the IAD Framework to Analyze Fisheries Policy. Society and Natural Resources, 18, 493-509. http://dx.doi.org/10.1080/08941920590947922

Jentoft, S. (1989). Fisheries co-management: delegating government responsibility to fishermen's organizations. Marine Policy, 13, 137-54. http://dx.doi.org/10.1016/0308-597X(89)90004-3

Leithwood, K. A., \& Poplin, M. S. (1992). The Move toward Transformational Leadership. Educational Leadership, 49, 5; Research Library pg. $8 . \quad$ URL: http://edst.educ.ubc.ca/sites/edst.educ.ubc.ca/files/courses/eadm/eadm582_transformational1. pdf

Murphy, L. (2005). Transformational leadership: a cascading chain reaction. Journal of Nursing Management, 13(2), 128-136. http://dx.doi.org/10.1111/j.1365-2934.2005.00458.x

NFP (National Fish Policy). 1998. C/O Department of Fisheries Bangladesh. 78 pages

Ostrom, E. (1990). Governing the Commons: The Evolution of Institutions for Collective Action. Cambridge University Press: Cambridge. http://dx.doi.org/10.1017/CBO9780511807763

OPR 4 (Options for Purpose Reviews 4). (2005). Independent Review of WorldFish center. Unpublished Report. 125 pages

Parry, K. W., \& Bryman, A. (1996). Handbook of organizational studies. URL: http://coursesite.uhcl.edu/BPA/elden/HMRS6733/Leadership\%20in\%20Organizations.pdf

Pero, L.V., \& Smith, T. F. (2008). Institutional credibility and leadership: critical challenges for community-based natural resource governance in rural and remote Australia. Regional Environmental Change, 8: 15-29. http://dx.doi.org/10.1007/s10113-007-0042-4

Pinkerton, E. (2003). Towards specificity in complexity: understanding comanagement from a social science perspective, p. 61-77. In Pinkerton, Evelyn; Wilson, Douglas C.; Nielsen, Jesper Raakjaer; Degnbol, Poul (eds). The Fisheries Co-Management Experience: Accomplishments, Challenges and Prospects. Kluwer Academic Publishers. 
http://dx.doi.org/10.1007/978-94-017-3323-6_5

Pinkerton, E. W. (1989). Introduction: Attaining Better Fisheries Management through Comanagement

Pirnini, N. (2011). Governance reforms and anti-corruption commission in Bangladesh. Governance and Corruption, 11(1). URL: http://www.sar.org.ro/polsci/?p=587

Platteau, J. P., \& Gaspart, F. (2003). Disciplining local leaders in community-based development. C/O Centre for Research on the Economics of Development (CRED), Faculty of Economics. Rempart de la Vierge, 8 B-5000 Namur Belgium

Pomeroy, R. C., \& Rebecca, R. G. (2006). Fisheries comanagement: A practical handbook. CAB international and IDRC 285 pages

Plummer, R., \& FitzGibbon, J. (2006). People matter: The importance of social capital in the co-management of natural resources. Natural Resources Forum, 30, 51-62. http://dx.doi.org/10.1111/j.1477-8947.2006.00157.x

Plummer, R, \& Fennel. (2007). Exploring co-management theory: Prospects for sociobiology and reciprocal altruism. Journal of Environmental Management, 85, 944-955. http://dx.doi.org/10.1016/j.jenvman.2006.11.003

Prager, K. (2010). Local and regional partnerships in natural resource management: the challenge of bridging institutional levels. Environmental Management, 46(5), 711-24. http://dx.doi.org/10.1007/s00267-010-9560-9

Ratner, B. D., Oh, E. J. V., \& Pomeroy, R. S. (2012). Navigating change: Second-generation challenges of small-scale fisheries co-management in the Philippines and Vietnam. Journal of Environmental Management, 107, 131-139. http://dx.doi.org/10.1016/j.jenvman.2012.04.014

Reitcher, S., Hasslam, S. A., \& Hopkins, N. (2005). Social identity and dynamics of leadership: Leaders and followers as collaborative agents in Transformation of social reality. Leadership. 547-568. http://dx.doi.org/10.1016/j.leaqua.2005.06.007

Ross, A. H., Robinson, C. J., \& Hockings, M. T. (2005). Evaluation of indigenous co-management of natural resources. In: Jennifer Bellamy, Regional Natural Resource Management Planning: The challenges of evaluation as seen through different lenses. CIRM Social Dimensions of NRM Working Group, Brisbane, Australia, (51-58). 15 October 2004

SEHD (Society for Environment and Human Development). (2002). Bangladesh environment facing the $21^{\text {st }}$ Century. $391 \mathrm{pp}$.

Stogdil, R. M. (1974). Handbook of leadership: A survey of the literature, New York: Free Press.

Thompson, P. M. (2003). Understanding livelihoods dependency on inland fisheries in Bangladesh and Southeast Asia. DFID/FMSP Project R8118. Bangladesh Summary report. Retrieved from http://www.ahj00.dial.pipex.com/r8118/r8118_13.pdf 
Townsley, P. (1996). Rapid rural appraisal, participatory rural appraisal and aquaculture. FAO $\begin{array}{lllll}\text { Fisheries } & \text { Technical } & \text { Paper } & \text { Retrieved from }\end{array}$ http://www.fao.org/docrep/006/w2352e/W2352E00.htm\#TOC

Treseder, L. C. (2000). Forest comanagement in Northern Alberta: Conflict sustainability, and Power. Masters Thesis. Department of Renewable Resources. University of Alberta. Edmonton, Alberta.

Tyler, T.R. \& De Cremer, D. (2005). Process-based leadership. Process-based leadership. Fair procedure and reaction to organizational change. Leadership, 16, 529-545. http://dx.doi.org/10.1016/j.leaqua.2005.06.001

UKaid. (2010). Liquid assets: community-based fisheries management in Bangladesh (PDF) Retrieved from http://www.worldfishcenter.org/resource_centre/DFID\%20impact\%20case\%20study\%20CBF M\%20in\%20Bangladesh\%20-\%20March\%202010.pdf

Uphoff, N. (1999). Local Institutions and Participation for Sustainable Development. Gatekeeper Series No. SA31. International Institute for Environment and Development. Retrieved from http://pubs.iied.org/pdfs/6045IIED.pdf

van Knippenberg, D., De Dreu, C. K. W., \& Homan, A. C. (2004). Work group diversity and group performance: An integrative model and research agenda. Journal of Applied Psychology, 89, 1008-1022. http://dx.doi.org/10.1037/0021-9010.89.6.1008

WorldFish Center, Bangladesh. (2003). Annual Report. Community-based fisheries management project (Phase-2). World Fish Center, Dhaka, Bangladesh, pp. 165-175

WorldFish Center, Bangladesh. (2007). Community-based fisheries management: Fisheries yields and sustainability. Policy Brief No. 2. Pp- 4. Retrieved from http://www.worldfishcenter.org/resource_centre/Fisheries\%20Yields\%20and\%20sustainabilit ies.pdf

Yin, R. (2002). Case study research: Designs and methods. Revised ed. Sage Publication.

\section{Copyright Disclaimer}

Copyright for this article is retained by the author(s), with first publication rights granted to the journal.

This is an open-access article distributed under the terms and conditions of the Creative Commons Attribution license (http://creativecommons.org/licenses/by/3.0/). 